\title{
EFFECT OF SILYBUM MARIANUM (L.) GAERTN. ON GERMINATION, EARLY GROWTH AND NUTRIENT UPTAKE OF ZEA MAYS L.
}

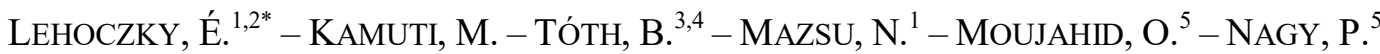 \\ ${ }^{1}$ Institute of Soil Sciences and Agricultural Chemistry, Centre for Agricultural Research, \\ Hungarian Academy of Sciences, 1022 Budapest, Herman O. u. 15., Hungary \\ ${ }^{2}$ Faculty of Agricultural Sciences and Rural Development, Eszterházy Károly University \\ 3200 Gyöngyös, Mátrai út 36., Hungary \\ ${ }^{3}$ Institute of Nutrition, University of Debrecen, 4032 Debrecen, Egyetem tér 1., Hungary \\ ${ }^{4}$ Present address: Department of Plant Sciences, University of the Free State \\ P.O. Box 339, Bloemfontein 9300, Republic of South Africa \\ ${ }^{5}$ Dow AgroSciences Export SAS, Sophia Antipolis Cedex, France \\ *Corresponding author \\ e-mail:lehoczky.eva@agrar.mta.hu \\ (Received $18^{\text {th }}$ Oct 2017; accepted $27^{\text {th }}$ Feb 2018)
}

\begin{abstract}
In our experiment, the effect of water extract of Silybum marianum (L.) Gaertn. on germination and early growth of Zea mays L. was examined in laboratory circumstances. The examined concentrations $(\mathrm{m} / \mathrm{v} \%)$, originated from dried $S$. marianum water extract were the following: $1 \%, 5 \%$, $7.5 \%$ and $10 \%$. The fresh and dry weight of maize, the length of coleoptile and radicle and the nutrient element contents were measured. The results demonstrate that the $1 \%$ milk thistle water extract treatment has a significant positive effect on all of the measured parameters of maize. In the case of higher concentrations, the fresh and dry weight of coleoptile significantly decreased compared to the control. The same tendency can be observed for the radicle. $\mathrm{N}, \mathrm{K}, \mathrm{Ca}, \mathrm{Mg}$ and $\mathrm{Zn}$ concentration of radicle and $\mathrm{K}$, $\mathrm{Ca}$ and $\mathrm{Zn}$ concentration of coleoptile increased when maize was treated with milk thistle extract, at all kind of concentration levels. The $\mathrm{Cu}$ and $\mathrm{Fe}$ content of maize seedlings decreased at all applied concentrations. Our results demonstrate the importance of S. marianum's appearance in field because it has very strong allelopathic effects. Further examination is needed to determine if the remaining plant residues have an effect on germination and growth of crops.
\end{abstract}

Keywords: biomass production, corn, milk thistle, growth inhibition

\section{Introduction}

Allelopathy refers to the beneficial or harmful effects of one plant on another plant, both crop and weed species, from the release of biochemicals, known as allelochemicals, to plant parts by leaching, root exudation, volatilization, residue decomposition and other processes in both natural and agricultural systems. Allelochemicals are a subset of secondary metabolites not required for metabolism (growth and development) of the allelopathic effects and are important part of plant defence against herbivory (Fraenkel, 1959; Stamp, 2003).

Commonly cited effects of allelopathy include reduced seed germination and seedling growth (Lehoczky et al., 2011a, b, 2014). Inhibition due to allelopathy is complex and can involve the interaction of different chemical classes, like phenolic compounds, flavonoids, terpenoids, alkaloids, steroids, carbohydrates and amino acids 
with different compound mixtures sometimes having higher allelopathic effect than individual compounds alone (Győri et al., 2014; Lehoczky et al., 2016; Nwaichi and Ayalogu, 2010).

The basic approach used in allelopathic research for agricultural crops has been to screen both crop plants and natural vegetation for their capacity to suppress weeds (Lehoczky and Gólya, 2013). To demonstrate the phenomenon and mechanism of allelopathy, plant origin, production, and identification of allelochemicals have to be established as well as persistence in the environment over time in concentrations sufficient to affect different plant species. Interactions among allelopathic plants, host crops, and other non-target organisms must also be considered (Ferguson and Rathinasabapathi, 2012).

Many researchers have documented the allelopathic effect of milk thistle on mustard, cucumber, wheat and sorghum (Isam and Hussain, 1988), but there is little knowledge on the effect on maize. Qasem and Foy (2008) established, that milk thistle have the potential to be used in solving problems of other weed species and represents an excellent source of natural chemicals that may be involved in developing natural herbicides.

S. marianum is by far the most widely known species. Milk thistle, also known as the Marian, St. Mary's or Our Lady's thistle, is native to the Mediterranean region of Europe and is grown commercially as a medical plant in Egypt, Tunisia, China and Argentina (Anonymous, 1995; Penksza and Szerdahelyi, 2009) but it has been reported as a noxious weed in many other countries. Otherwise, milk thistle is a serious weed in many areas of North and South America, Africa, Australia and the Middle East (Holm et al., 1997).

Weeds are an important variable in crop production (Bilalis et al., 2010; Efthimiadou et al., 2009; Karkanis et al., 2010; Lehoczky et al., 2013, 2015). Weed science will be advantageously positioned in the future if research focuses on research - decision process, weed biology and ecology, weed control and management practices, herbicide resistance, issues related to transgenic plants, environmental issues, and potential benefits of weeds (Hall et al., 2000).

Weeds have serious effect on crop production. Nowadays, the milk thistle is one of the most prevalent weeds found in the fields in North Africa. This research will be positioned for the future, focusing on interaction, weed biology and ecology, weed control and management practices, herbicide resistance.

The basic aim of the experiment was to make bioassay examination which assesses the allelopathic effects of Silybum marianum (L.) Gaertn. on maize seedlings in laboratory circumstances. The test plant's (maize) element composition, germination and growth inhibition were also investigated at the end of the experiment.

\section{Materials and methods}

The Silybum marianum (L.) Gaertn. leaves were dried on $45^{\circ} \mathrm{C}$. After drying, the sample was chopped than milled. The plant material of $S$. marianum was collected from agricultural area. The element content of milk thistle is shown in Table 1.

The first $150 \mathrm{ml}$ of the $10 \%$ concentration water extract was made by soaking $15 \mathrm{~g}$ powdered plant sample in $150 \mathrm{ml}$ tap water. The mixture was kept at room temperature for $24 \mathrm{~h}$ and was mixed occasionally. After $24 \mathrm{~h}$, the extract was filtered through $\mathrm{MN}$ $619 \mathrm{G} 1 / 4$ filter paper. The $10 \%$ concentration water extract was diluted to obtain the 
concentrations of $1 \%, 5 \%$ and $7.5 \%$. Tap water was used as a control (Ø). Twenty maize seeds (Zea mays L.) were placed separately into $18 \mathrm{~cm}$ diameter Petri dishes on MN $640 \mathrm{~m}$ filter paper. $15 \mathrm{ml}$ of each concentration of water extracts were added to the Petri dishes in four replications. All of them were placed in a Binder APT Line KBW plant growing chamber at $21 \pm 1{ }^{\circ} \mathrm{C}$ for 7 days.

Table 1. Element content of Silybum marianum L. Gaertn. leaves $\left(m g \mathrm{~kg}^{-1}, N(\%)\right) N=2 \pm$ $S D$

\begin{tabular}{c|c|c|c|c}
\hline $\mathbf{N}$ & $\mathbf{P}$ & $\mathbf{K}$ & $\mathbf{C a}$ & $\mathbf{M g}$ \\
\hline $2.42 \pm 0.09$ & $1764 \pm 42$ & $34165 \pm 54$ & $35432 \pm 2917$ & $5156 \pm 59$ \\
\hline $\mathbf{F e}$ & $\mathbf{M n}$ & $\mathbf{C u}$ & $\mathbf{Z n}$ & $\mathbf{M o}$ \\
\hline $321 \pm 86$ & $30.4 \pm 2.4$ & $14.8 \pm 0.7$ & $43.5 \pm 0.5$ & $1.07 \pm 0.15$ \\
\hline
\end{tabular}

The used experimental design and method have already been published by Lehoczky et al., (2011a, b, 2017).

Seven days after the start of the experiment, the shoots and roots of every seedling were measured with millimetre paper. The fresh weight of the shoots and roots was determined at the same time. After drying, the dry weight was also measured.

Determination of the seedling nutrient concentrations for $\mathrm{P}, \mathrm{K}, \mathrm{Ca}, \mathrm{Mg}, \mathrm{Fe}, \mathrm{Mn}, \mathrm{Cu}$, $\mathrm{Zn}$ and Mo was carried out with ICP-OES method after microwave Teflon bomb digestion with cc. $\mathrm{HNO}_{3}+\mathrm{H}_{2} \mathrm{O}_{2}$. The nitrogen concentration of samples was determined using the Kjeldahl method.

The substances with allelopathic effects of the Silybum marianum L. Gaertn. sample have been investigated by HPLC. According to the methanol extract, $1 \mathrm{~g}$ plant sample contained $63 \mu \mathrm{g}$ rutin and $194 \mu \mathrm{g}$ salicylic acid. Both rutin and salicylic acid have inhibitory effects on germination (Basile et al., 2000; Szepesi, 2009; Szabó, 1997).

ANOVA (Analysis of Variance) was used to evaluate the significant differences. On the figures the error bars indicate the standard deviation and the a-e indicate significant differences within treatments at the 5\% level of probability according to Duncan's test. For the statistical analysis Sigma Plot 12.0 was used. Examinations were carried out in three replications and in different cases with four replications. The experiments were conducted in controlled environmental conditions, so there was no difference between the results of three biological replications. The data of three repetitions were summarized and used for statistical analysis - results were calculated from twelve data.

\section{Results}

Usually, the effects of allelopathy include reduced seed germination and seedling growth. All maize seeds started to germinate by the end of the seventh day, hence the germination percentage was $100 \%$ in all treatments. However, the number of seeds with a length of a few $\mathrm{mm}$ shoot have increased in parallel with increasing extract concentration (Fig. 1a, b).

Decrease of shoot and radicle length was observed at the 5, 7.5 and $10 \%$ extract treatments. The length of shoot increased by $18 \%$ in the $1 \%$ extract treatment. The increase is significant compared to the control. The length of radicle increased by $18 \%$ 
in the $1 \%$ milk thistle extract treatment. The decrease is parallel with the increasing concentration of milk thistle extracts.

a

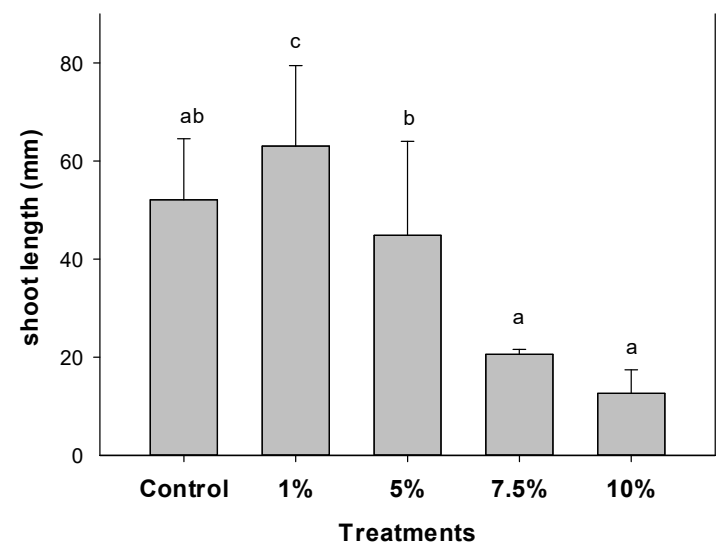

b

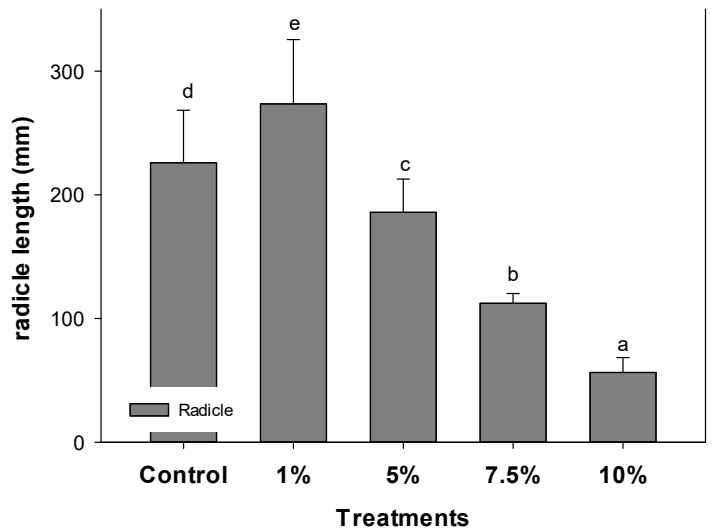

Figure 1. The effect of Silybum marianum L. Gaertn. water extracts (a) on the length of shoot of maize $\left(L S D_{5 \%}\right.$ 12.36) $N=240 \pm S D$ and (b) on the length of radicle of maize $\left(L S D_{5 \%} 49.80\right)$

$$
N=240 \pm S D
$$

Additionally, the effect of $S$. marianum was observed on the fresh weight of shoot (coleoptile) and root (radicle) of maize (Fig. 2a,b).

a

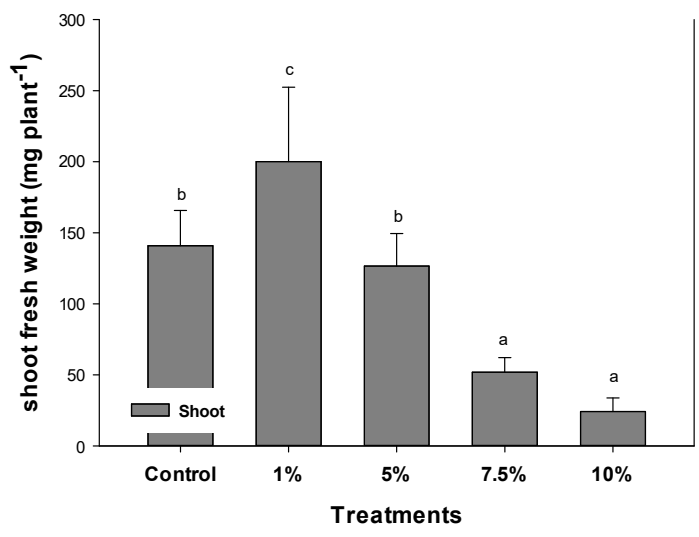

b

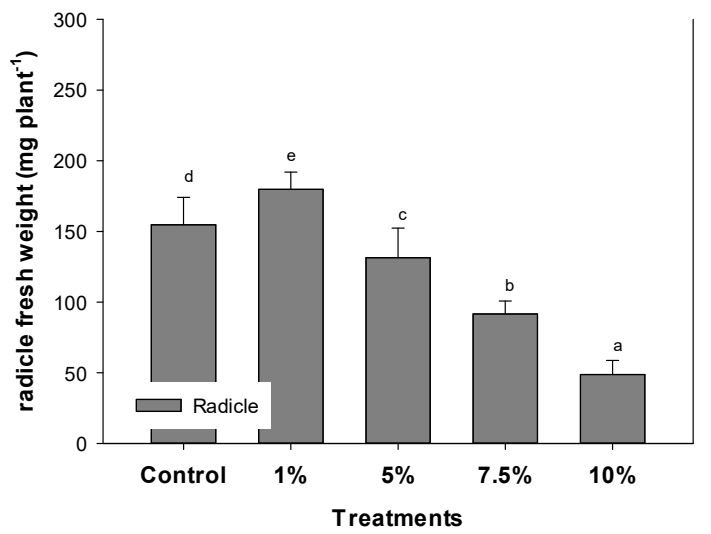

Figure 2. The effect of Silybum marianum L. Gaertn. water extracts (a) on the fresh shoot weight of maize $\left(L S D_{5 \%} 35.11\right) N=12 \pm S D$ and (b) on the fresh radicle weight of maize $\left(L S D_{5 \%}\right.$ 18.86) $N=12 \pm S D$

The positive effect was observed when $1 \%$ extract was applied. The fresh weight of coleoptile was significantly increased by $30 \%$ in the $1 \%$ treatment. At the higher concentrations, the effect was negative on fresh weight. The fresh weight of shoot decreased by $11 \%, 64 \%$ and $83 \%$ in the $5 \%, 7.5 \%$ and $10 \%$ treatment, respectively. In the case of the highest concentration the decrease was significant compared to the control. The same tendency can be observed in the case of the fresh weight of radicle (Fig. 2b). The fresh weight of radicle increased by $14 \%$ in the $1 \%$ extract treatments. 
Decrease was observed at the higher concentration. The highest decrease was in the case of the $10 \%$ extract treatment. The dry weight of shoots and radicles also were measured (Fig. 3a,b).

a

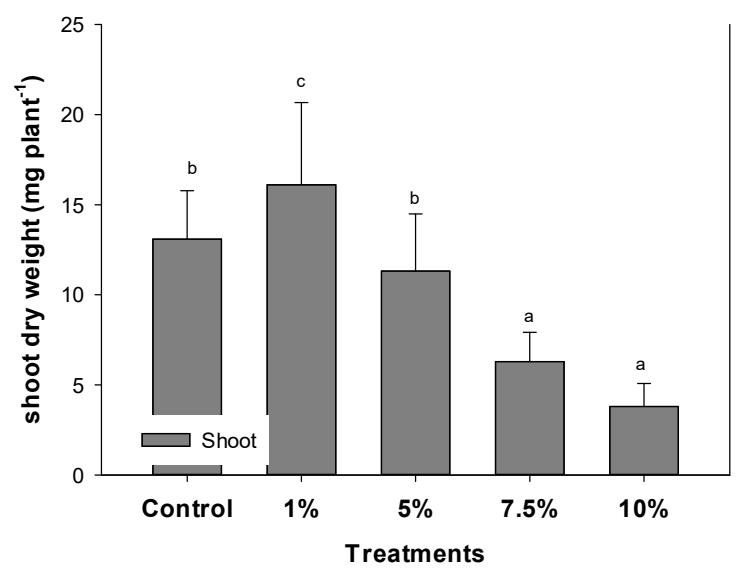

b

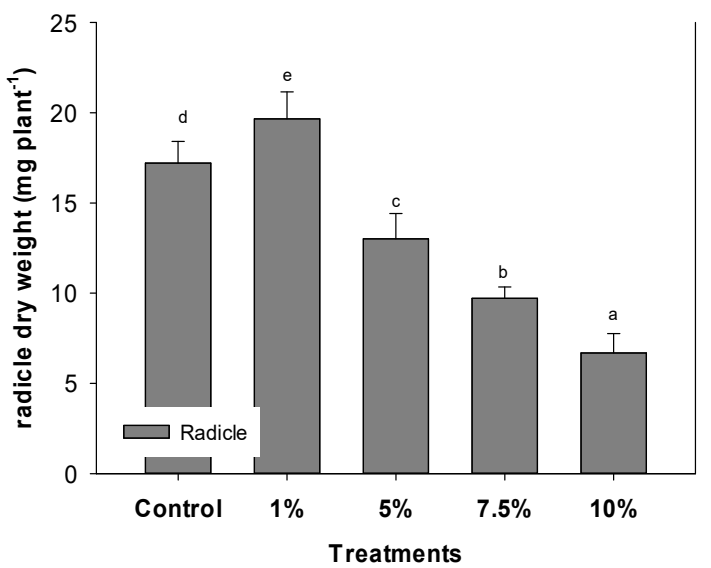

Figure 3. The effect of Silybum marianum L. Gaertn. water extracts (a) on the dry weight of shoot of maize $\left(L S D_{5 \%} 4.06\right) N=12 \pm S D$ and (b) on the dry weight of radicle of maize $\left(L S D_{5 \%}\right.$ 1.72) $N=12 \pm S D$

The $1 \%$ extract treatment had less positive effect on dry weight than on fresh weight of shoot. The dry weight of shoot increased with 19\%. The decrease at the higher extract concentrations also had less negative effect on the dry weight of shoots as well as on the fresh weight of shoot. The decrease was mathematically proven in both cases.

Figure 4 shows the different extract treatments on the shoot/root dry weight rate of maize. The shoot/root dry weight ratio of seedlings was higher in the case of 1 and 5\% concentrations compared to the control $(0.76)$, which is a trend that is not statistically significant.

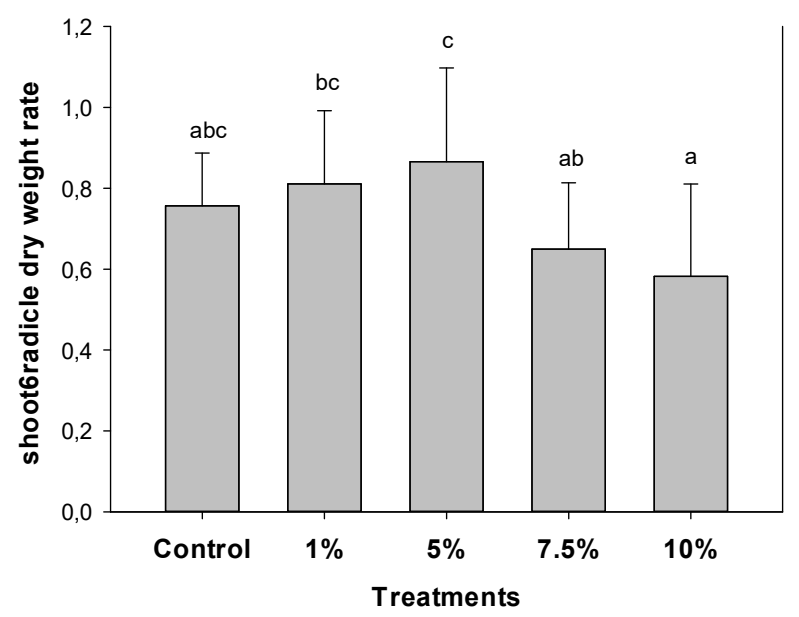

Figure 4. The effect of Silybum marianum L. Gaertn. water extracts on the shoot/root dry weight rate of maize $\left(L S D_{5 \%} 0.33\right) N=12 \pm S D$ 
In the case of the $1 \%$ extract treatment, the mass of the root and shoot both increased, but the increase of shoot weight was greater than of root weight. Similar results were observed at 5\% concentration level regarding the ratio, however the root and shoot growth was also inhibited (Fig. 3a, b). The inhibitory effect was more strongly manifested in the case of roots, which explains the growth of shoot/root dry weight ratio shown in Figure 4. In the case of the 7.5 and $10 \%$ extract treatments the shoot/root ratio was significantly lower compared to the treatment with $5 \%$ concentration. The background in both cases is the strong growth inhibiting effect of the extracts, in which the shoot growth inhibition was stronger than the root growth inhibition, thus the significant reduction of the ratio can be explained.

Tables 2 and 3 show the element concentrations of shoot and radicle of maize. The concentration of $\mathrm{N}$ is significantly decreased in shoot in $1 \%$, and increased in 5, 7.5 and $10 \%$ treatment in radicle. The concentration of $\mathrm{P}$ significantly decreased by $22 \%$ in the $10 \%$ extract treatment in shoot compared to the control, but there was no significant difference detected in radicle between $S$. marianum treatments and control. The concentration of $\mathrm{K}$ is significantly increased in both shoot and radicle in 5\%, 7.5\% and $10 \%$ water extracted milk thistle treatments. The increment is $36 \%, 32 \%$ and $36 \%$ in shoot, and $53 \%, 54 \%$ and $56 \%$ in radicle, respectively. The concentration of $\mathrm{K}$ was not changed significantly parallel with the increasing water extract concentration. The content of calcium significantly increased in all extract treatments; the highest increase could be observed at 7.5\% water extract concentration in shoot and at 5\% in radicle treatment compared to the control. In order to protect roots against the adverse effects of high concentrations of various other cations in the soil solution, the $\mathrm{Ca}^{2+}$ concentrations required for optimal growth have to be substantially higher in soil solution than in balanced flowing nutrient solutions (Asher and Edwards, 1983). Also increment was determined in the $\mathrm{Mg}$ content in the radicle of maize when maize was treated with milk thistle extract. $\mathrm{Mg}$ is also required for optimal plant growth. At permanently insufficient root supply, remobilization of $\mathrm{Mg}$ from mature leaves reduces their longevity (Lange et al., 1987). The content of $\mathrm{Cu}$ decreased parallel with the increasing extract concentration. The Fe content decreased in the all treatments. The concentration of molybdenum in shoot was changed significantly in the $10 \%$ treatments, while no significantly changes were observed in radicle compared to the control.

\section{Discussion}

Allelopathic effect of milk thistle on different crops has been documented sporadically, but there is no literature on its effect on maize.

Therefore, a laboratory based allelopathic extracts bioassay was conducted. During our experimental period the allelopathic effects of donor species on germination and seedling growth of maize was observed. Results has been shown, Silybum marianum L. extract did not have any effect on the germination of maize. The maize seedlings growth was inhibited by 5, 7.5 and $10 \%$ extract of Silybum marianum L. but growth stimulation effect was observed by $1 \%$ concentration extract.

Sultana and Asaduzzaman (2012) also observed inhibition effect on the abovementioned parameters in case of canola and ryegrass. They established that the extracts from fresh water at $100 \%$ was more toxic to receiver species followed by $50 \%$ concentration of fresh and $100 \%$ from hot water extracts. This concentration reduced the root, shoot growth of ryegrass and canola by $84.97 \%, 84.27 \%$ and $89.90 \%$, 
respectively. The result also revealed that the allelopathic pattern of hot water extracts was the same; however, it was less toxic to both receiver species.

Table 2. Element concentrations of shoot of maize treated with 1, 5, 7.5 and 10\% milk thistle water extract treatments $\left(\mathrm{mg} \mathrm{kg}^{-1}, N(\%)\right) \mathrm{N}=2 \pm S D$

\begin{tabular}{c|c|c|c|c|c}
\hline & $\mathbf{N}$ & $\mathbf{P}$ & $\mathbf{K}$ & $\mathbf{C a}$ & $\mathbf{M g}$ \\
\hline Control & $5.7 \pm 0.2 \mathrm{~b}$ & $9752 \pm 412 \mathrm{~b}$ & $24458 \pm 4353 \mathrm{a}$ & $210 \pm 42 \mathrm{a}$ & $1805 \pm 97 \mathrm{a}$ \\
$\mathbf{1 \%}$ & $5.1 \pm 0.2 \mathrm{a}$ & $9789 \pm 209 \mathrm{~b}$ & $27259 \pm 1410 \mathrm{a}$ & $623 \pm 8 \mathrm{~b}$ & $1834 \pm 21 \mathrm{a}$ \\
$\mathbf{5 \%}$ & $5.6 \pm 0.0 \mathrm{~b}$ & $9551 \pm 245 \mathrm{~b}$ & $38087 \pm 1979 \mathrm{~b}$ & $763 \pm 51 \mathrm{~b}$ & $1834 \pm 1 \mathrm{a}$ \\
$\mathbf{7 . 5 \%}$ & $5.8 \pm 0.1 \mathrm{~b}$ & $9382 \pm 345 \mathrm{~b}$ & $35635 \pm 707 \mathrm{~b}$ & $779 \pm 129 \mathrm{~b}$ & $1881 \pm 96 \mathrm{a}$ \\
$\mathbf{1 0 \%}$ & $5.7 \pm 0.1 \mathrm{~b}$ & $7636 \pm 624 \mathrm{a}$ & $38043 \pm 5139 \mathrm{~b}$ & $762 \pm 196 \mathrm{~b}$ & $1962 \pm 4 \mathrm{a}$ \\
\hline Mean & 5.6 & 9222 & 32696 & 627 & 1863 \\
LSD5\% & 0.4 & 1056 & 8136 & 304 & 192 \\
\hline \hline Control & $84.4 \pm 10.7 \mathrm{~d}$ & $9.4 \pm 0.1 \mathrm{~b}$ & $7.5 \pm 1.5 \mathrm{~b}$ & $35.4 \pm 6.3 \mathrm{a}$ & $0.43 \pm 0.04 \mathrm{~b}$ \\
$\mathbf{1 \%}$ & $76.9 \pm 11.7 \mathrm{~cd}$ & $9.5 \pm 0.8 \mathrm{~b}$ & $6.7 \pm 0.9 \mathrm{ab}$ & $35.2 \pm 1.7 \mathrm{a}$ & $0.38 \pm 0.03 \mathrm{~b}$ \\
$\mathbf{5 \%}$ & $63.5 \pm 0.1 \mathrm{bc}$ & $9.1 \pm 0.5 \mathrm{~b}$ & $5.3 \pm 0.2 \mathrm{a}$ & $45.8 \pm 2.3 \mathrm{ab}$ & $0.41 \pm 0.01 \mathrm{~b}$ \\
$\mathbf{7 . 5 \%}$ & $51.1 \pm 5.9 \mathrm{ab}$ & $8.5 \pm 0.9 \mathrm{~b}$ & $4.7 \pm 0.4 \mathrm{a}$ & $45.8 \pm 3.4 \mathrm{ab}$ & $0.42 \pm 0.03 \mathrm{~b}$ \\
$\mathbf{1 0 \%}$ & $39.9 \pm 1.4 \mathrm{a}$ & $6.1 \pm 0.3 \mathrm{a}$ & $4.8 \pm 0.0 \mathrm{a}$ & $51.5 \pm 4.5 \mathrm{~b}$ & $0.23 \pm 0.09 \mathrm{a}$ \\
\hline Mean & 63.1 & 8.5 & 5.8 & 42.8 & 0.37 \\
LSD5\% & 23.0 & 2.0 & 1.7 & 5.1 & 0.15 \\
\hline
\end{tabular}

Note: different letters indicate significant difference $(\mathrm{P}<0.05)$

Table 3. Element concentrations of radicle of maize treated with 1, 5, 7.5 and $10 \%$ milk thistle water extract treatments $\left(\mathrm{mg} \mathrm{kg}^{-1}, N(\%)\right) \mathrm{N}=2 \pm S D$

\begin{tabular}{c|c|c|c|c|c}
\hline & $\mathbf{N}$ & $\mathbf{P}$ & $\mathbf{K}$ & $\mathbf{C a}$ & $\mathbf{M g}$ \\
\hline Control & $3.6 \pm 0.1 \mathrm{a}$ & $6894 \pm 413 \mathrm{a}$ & $22883 \pm 2593 \mathrm{a}$ & $425 \pm 67 \mathrm{a}$ & $1362 \pm 162 \mathrm{a}$ \\
$\mathbf{1 \%}$ & $3.5 \pm 0.2 \mathrm{a}$ & $6830 \pm 361 \mathrm{a}$ & $27693 \pm 1699 \mathrm{a}$ & $2967 \pm 749 \mathrm{~b}$ & $1908 \pm 100 \mathrm{a}$ \\
$\mathbf{5 \%}$ & $4.2 \pm 0.2 \mathrm{~b}$ & $7348 \pm 31 \mathrm{a}$ & $48743 \pm 3604 \mathrm{~b}$ & $5116 \pm 337 \mathrm{c}$ & $3972 \pm 441 \mathrm{~b}$ \\
$\mathbf{7 . 5 \%}$ & $4.6 \pm 0.1 \mathrm{~b}$ & $7358 \pm 270 \mathrm{a}$ & $50157 \pm 4391 \mathrm{~b}$ & $4736 \pm 671 \mathrm{c}$ & $4027 \pm 276 \mathrm{~b}$ \\
$\mathbf{1 0 \%}$ & $5.6 \pm 0.3 \mathrm{c}$ & $7271 \pm 332 \mathrm{a}$ & $51724 \pm 2579 \mathrm{~b}$ & $3104 \pm 864 \mathrm{~b}$ & $3794 \pm 429 \mathrm{~b}$ \\
\hline Mean & 4.3 & 7140 & 40240 & 3270 & 3013 \\
$\boldsymbol{L S D 5 \%}$ & 0.5 & 898 & 9538 & 1787 & 620 \\
\hline \hline & $\mathbf{F e}$ & $\mathbf{M n}$ & $\mathbf{C u}$ & $\mathbf{Z n}$ & Mo \\
\hline Control & $57.3 \pm 2.8 \mathrm{c}$ & $6.0 \pm 2.1 \mathrm{a}$ & $24.1 \pm 5.1 \mathrm{c}$ & $34.6 \pm 5.2 \mathrm{ab}$ & $0.25 \pm 0.06 \mathrm{ab}$ \\
$\mathbf{1 \%}$ & $54.8 \pm 1.5 \mathrm{c}$ & $5.1 \pm 0.7 \mathrm{a}$ & $15.9 \pm 1.8 \mathrm{~b}$ & $32.4 \pm 3.5 \mathrm{a}$ & $0.36 \pm 0.06 \mathrm{ab}$ \\
$\mathbf{5 \%}$ & $52.2 \pm 2.2 \mathrm{bc}$ & $5.4 \pm 0.5 \mathrm{a}$ & $13.3 \pm 0.1 \mathrm{ab}$ & $40.1 \pm 1.6 \mathrm{ab}$ & $0.39 \pm 0.02 \mathrm{~b}$ \\
$\mathbf{7 . 5 \%}$ & $47.9 \pm 3.4 \mathrm{ab}$ & $5.1 \pm 0.3 \mathrm{a}$ & $11.2 \pm 1.6 \mathrm{ab}$ & $42.2 \pm 3.4 \mathrm{~b}$ & $0.29 \pm 0.12 \mathrm{ab}$ \\
$\mathbf{1 0 \%}$ & $42.4 \pm 2.1 \mathrm{a}$ & $5.2 \pm 0.4 \mathrm{a}$ & $8.8 \pm 0.2 \mathrm{a}$ & $51.2 \pm 1.7 \mathrm{c}$ & $0.19 \pm 0.02 \mathrm{a}$ \\
\hline Mean & 50.9 & 5.3 & 14.7 & 40.1 & 0.29 \\
$\boldsymbol{L S D 5 \%}$ & 2.0 & 2.8 & 7.2 & 8.9 & 0.20 \\
\hline
\end{tabular}

Note: different letters indicate significant difference $(\mathrm{P}<0.05)$ 
The allelopathic potential of $S$. marianum was investigated by Khan et al. (2011) on kidney bean (Phaseolus vulgaris L.), mung bean (Vigna radiate L.), chickpea (Cicer arietinum L.) and soybean (Glycine max L.). The results show that by increasing the leaves extract concentration of $S$. marianum, a significant decrease was noted in the germination percentage, mean germination time, germination index and seed vigor index of test species. The tolerance order of the mung bean and soybean against the extract concentration of $S$. marianum was higher than the other two species, while the chickpea was more susceptible to the toxicity of milk thistle.

Milk thistle is a major weed in sugar beet, wheat and canola causing large yield reductions (Shimi et al., 2006). However, research has documented the allelopathic effect of milk thistle on mustard, cucumber, wheat and sorghum (Inam and Hussain, 1988; Lehoczky et al., 2017).

In our experiment, the uptaken elements, e.g. K, Ca and $\mathrm{Zn}$, were increased both in the shoot and root when maize was treated with $S$. marianum, but the $\mathrm{Cu}$ and $\mathrm{Fe}$ content decreased as a result of the milk thistle extract treatment.

In summary, the microelement concentrations decreased by the application of milk thistle water extracts. The micronutrients have prominent effect on dry matter, grain and straw yield (Aller et al., 1990). Fe plays role e.g. in nitrogen fixation (Römheld and Marschner, 1991) and it is very essential for normal plant growth (Fageria, 2007). Mn is utilized in enzyme activation (Burnell, 1988), $\mathrm{Zn}$ is important to membrane integrity and protein synthesis (Zhao et al., 2012). So, the adequate uptake of micronutrients has an effect on plant growth and development. Otherwise, plant will suffer from growth inhibition.

Seed germination is affected by the nutritional status of the mother plant and therefore by nutrient concentration in the seeds (Table 1). $\mathrm{P}$ and $\mathrm{K}$ concentrations of below $0.3 \%$ in seeds negatively affect their total germination (Hrdlicková et al., 2011). Seed germination and the time required for the $50 \%$ of the seeds to germinate are significantly affected by nitrogen (Hejcman et al., 2012). There was no detected inhibited germination in our experiment.

In our experiment the inhibition effect of milk thistle on the measured parameters of maize was also observed. Significant decrease was observed at increasing milk thistle extract concentration in the fresh and dry weight of shoot and radicles of maize, length of shoot and radicle. Compared to the stimulating 1\% treatment, the 5, 7.5 and $10 \%$ extract resulted in significant reduction of the fresh weight of coleoptile, which was 11 , 6 and $83 \%$, respectively. The length of shoot deceased by $12 \%$ in the $5 \%$ extract treatment, $60 \%$ in the 7.5 and $76 \%$ in the $10 \%$ milk thistle extract treatments. But a remarkable stimulating effect was observed in $1 \%$ extract treatment on the fresh weight (30\%) and length (14\%) of coleoptile.

Lehoczky et al. (2017) investigated the allelopathic effect of milk thistle on winter wheat. According to their results, the winter wheat is more sensitive for applied concentrations of $S$. marianum than the maize. The concentrations of $1 \%, 2 \%, 3 \%, 4 \%$ and $5 \%$ of water extract were used. They found that the allelopathic potential of milk thistle increased with increasing concentration. The fresh and the dry weight and the length of the shoot and radicle of wheat significantly decreased at 5\% concentration.

Recent assessment of allelopathic effect of weed on weed has the goal of using naturally produced allelochemicals to reduce reliance on herbicides (Putman and Duke, 1978). Milk thistle is a worldwide known weed. It has a special allelopathic effect, therefore, there is a significant difference when we grow milk thistle as medicinal plant 
or it acts as a weed. In the latter case, $S$. marianum may decrease the yield due to its allelopathic effect. So, special attention should be given to the plant residues of milk thistle to be worked in the soil after the vegetation period.

Acknowledgements. The authors gratefully acknowledge the support of the OTKA K-105789 Research Project and Dow AgroSciences. The first author was supported by the grant EFOP-3.6.1-16-2016-00001.

\section{REFERENCES}

[1] Aller, A. J., Bernal, J. L., Jesus del Nozal, M., Deban, L. (1990): Effects of selected trace elements on plant growth. - Journal of the Science of Food and Agricultural 51(4): 447479 .

[2] Anonymous (1995): Market report 1995. - Herbalgram 39: 68.

[3] Asher, C. J., Edwards, D. G. (1983): Modern Solution Culture Techniques. - In: Lauchli, A., Bieleski, R. L. (eds.) Encyclopedia of Plant Physiology, New Series, Vol. 15 A. Springer-Verlag, Berlin and New York.

[4] Barceloux, D. G. (2008): Medical toxicology of natural substances. - John Wiley and Sons, Hoboken, California.

[5] Basile, A., Sorbo, S., Giordano, S., Ricciardi, L., Ferrara, S., Montesano, D., Castaldo Cobianchi, R., Vuotto, M. L., Ferrara, L. (2000): Antibacterial and allelopathic activity of extract from Castanea sativa leaves. - Fitoterapia 71(Suppl.1): 110-116.

[6] Bilalis, D., Papastylianou, P., Konstantas, A., Patsiali, S., Karkanis, A. (2010): Weedsuppressive effects of maize-legume intercropping in organic farming. - International Jorunal of Pest Management 56: 173-181.

[7] Burnell, J. N. (1988): The Bioavailability of Manganese in Plants. - In: Graham, R. D., Hannan, R. J., Uren, N. C. (eds.) Manganese in Soilsand Plants, pp. 125-137. Kluwer Academic Publishers, Dordrecht.

[8] Efthimiadou, A., Karkanis, A., Bilalis, D., Efthimiadis, P. (2009): The phenomenon of crop-weed competition: a problem or a key for sustainable weed management? - Journal of Food, Agriculture and Environment 7: 861-868.

[9] Evans, W. C. (2002): Trease and Evans Pharmacology (15th ed.). - Reed Elsevier India Pvt. Ltd., New Delhi, India.

[10] Fageria, N. K. (2007): Soil fertility and plant nutrition research under field conditions: Basic principles and methodology. - Journal of Plant Nutrition 30(2): 203-223.

[11] Ferguson, J. J., Rathinasabapathi, B. (2012): Allelopathy: How plants suppress other plants. - African Traditional Herbal Research Clinic 7(3): 14-16.

[12] Fraenkel, G. S. (1959): The raison d'etre of secondary plant substances. - Science 129: 1466-1470.

[13] Győri, Z., Filep, T., Lehoczky, É. (2014): Trace element content of several weed seeds. Carpathian Journal of Earth and Environmental Sciences 9(2): 251-257.

[14] Hall, J. C., Van Eerd, L. L., Miller, S. D., Owen, M. D. K., Prather, T. S., Shaner, D. L., Singh, M., Vaughn, K. C., Weller, S. C. (2000): Future research directions for weed science. - Weed Technology 14: 647-658.

[15] Hejcman, M., Kristálová, V., Cervená, K., Hrdlicková, J., Pavlu, V. (2012): Effect of nitrogen, phosphorus and potassium availability on mother plant size, seed production and germination availability of Rumex crispus. - Weed Research 52(3): 260-268.

[16] Holm, L. G., Doll, J., Holm, E., Pancho, J., Herberger, J. (1997): World Weeds. Natural Histories and Distribution. - John Wiley and Sons, New York.

[17] Hrdlicková, J., Hejcman, M., Kristálová, V., Pavlu, V. (2011): Produciton, size and germination of broad-leaved dock seeds collected from mother plants grown unnder 
different nitrogen, phosphorous and potassium supplies. - Weed Biology and Management 11: 190-201.

[18] Inam, B., Hussain, F. (1988): Allelopathic effects of Silybum marianum Gaertn. - Sarhad Journal of Agriculture 4: 481-494.

[19] Karkanis, A., Bilalis, D., Efthimiadou, A., Efthimiadis, P. (2010): Cultural practices effects on weed flora in Virginia (flue-cured) organic tobacco (Nicotiana tabacum L.), green manure and irrigation system. - Turkish Journal of Agriculture and Forestry 34: 487-496.

[20] Khan, R., Khan, M. A., Waheedullah Waqas, M., Khan, A. M., Hussain, Z., Khan, A. (2011): Allelopathic potential of Silybum marianum L. against the seed germination of edible legumes. - Pakistan Journal of Weed Science Research 17(3): 293-302.

[21] Lange, O. L., Zellner, H., Gebel, J., Schameli, P., Köstner, B., Czygan, F. C. (1987): Photosynthetic capacity, chloroplast pigments, and mineral content of the previous year's needles with and without the new flush: analysis of the forest-decline phenomenon of needle bleeching. - Oecologia 73: 351-357.

[22] Lehoczky, É., Nelima, M. O., Szabó, R., Szalai, A., Nagy, P. (2011a): Allelopathic effect of Bromus spp. and Lolium spp. shoot extracts on some crops. - Communications in Agricultural and Applied Biological Sciences 76(3): 537-544.

[23] Lehoczky, É., Gólya, G., Szabó, R., Szalai, A. (2011b): Allelopathic effects of ragweed (Ambrisia artemissifolia L.) on cultivated plants. - Communications in Agricultural and Applied Biological Sciences 76(3): 545-549.

[24] Lehoczky, É., Gólya, G. (2013): Allelopathic effect of Ambrosia artemisiifolia L. on the early growth of winter wheat and maize. - Crop Production 62(1): 91-94.

[25] Lehoczky, É., Márton, L., Nagy, P. (2013): Competition for nutrients between coldtolerant maize and weeds. - Communications in Soil Science and Plant Analysis 44:(1-4): 526-534.

[26] Lehoczky, É., Nagy, P, Moujahid, O., Alimi, E. (2014): Allelopathic effect of Silybum marianum (L.) on winter wheat. - AIAC-2014: First Africa-International Allelopathy Congress: Allelopathy: Looking Ahead: Book of Abstracts of Plenary/Invited Lectures and Oral/Posters Presentations. February 6-9, 2014, Sousse, Tunisia.

[27] Lehoczky, É., Gólya, G., Tamás, J., Németh, T. (2015): Biodiversity and biomass production of weeds in a long-term fertilization experiment. - Communications in Soil Science and Plant Analysis 46:(1): 390-398.

[28] Lehoczky, É., Filep, T., Mazsu, N., Kamuti, M., Győri, Z. (2016): Variability in macro nutrient composition of weed seeds. - Applied Ecology and Environmental Research 14(3): 451-462.

[29] Lehoczky, É., Mazsu, N., Kamuti, M., Tóth, B., Moujahid, O., Nagy, P. (2017): Allelopathhic effect of Silybum marianum L. Gaertn. on growth and nutrient uptake of winter wheat (Triticum aestivum L.). - Applied Ecology and Environmental Research 15(4): 769-778.

[30] Nwaichi, E. O., Ayalogu, E. O. (2010): Allelopathy as expressed by Mucuna pruriens and the possibility for weed management. - International Journal of Plant Physiology and Biochemistry 2(1): 1-5.

[31] Penksza, K., Szerdahelyi, T. (2009): Silybum - Máriatövis. - In: Király, G. (ed.) Új magyar füvészkönyv. Aggteleki Nemzeti Park Igazgatóság, Jósvafö.

[32] Putman, A. R., Duke, W. B. (1978): Allelopathy in agro-ecosystem. - Annual Review of Phytopathology 16: 431-451.

[33] Qasem, J. R., Foy, C. L. (2008): Weed allelopathy, its ecological impacts and future prospects. - J. Crop Prod 4(2): 43-119.

[34] Rawn, D. F. K., Halldorson, T. H. J., Muir, D. C. G., Ballantine, L. G., McFarland, J. E., Hackett, D. S. (eds.) (1998): Triazines herbicides risk assessment. - ACS Symposium Series 683: 158-176. 
[35] Rawn, D. F. K., Halldorson, T. H. J., Lawson, B. D., Muir, D. C. G. (1999): A multi year study of four herbicides in air and precipitation from a small prairie watershed. - Journal of Environmental Quality 28: 898-906.

[36] Römheld, V., Marschner, H. (1991): Decrease in nitrate uptake and increase in proton release in zinc deficient cotton, sunflower and buckwheat plants. - Plant Soil 129: 216268.

[37] Shimi, P., Poorzavar, R., Jamali, M., Bagherani-Torshiz, N. (2006): Evaluating clopralid as a broad leaf herbicide in canola fields of Iran. - Pakistan Journal of Weed Sciences Research 12: 307-311.

[38] Stamp, N. (2003): Out of the Quagmire of plant defense hypotheses. - The Quarterly Review of Biology 78: 23-55.

[39] Szabó, L. Gy. (1997): Allelopathy, Phytochemical Potential, Life Strategy. - JPTEBornus, Pécs.

[40] Szepesi, Á. (2009): Effects of long-term salicylic acid treatments on salt stress acclimatisation of tomato plants (in Hungarian). - PhD Dissertation, University of Szeged, Hungary.

[41] Sultana, S., Asaduzzaman, M. (2012): Allelopathic studies on Milk Thistle (Silybum marianum). - International Journal of Agricultural Research, Innovation and Technology 2(1): 62-67.

[42] Zhao, H., Wu, L., Chai, T., Zhang, T., Tan, J., Ma, S. (2012): The effect of copper, manganese and zinc on plant growth and elemental accumulation in the manganesehyperaccumulator Phytolacca america. - J Plant Physiol 169(13): 1243-1252. 